\title{
STANDARDS FOR GOOD PHARMACY PRACTICE - A COMPARATIVE ANALYSIS
}

\author{
ANDREEA CHERTES, OFELIA CRIŞAN * \\ Pharmaceutical Legislation and Management, Faculty of Pharmacy, "Iuliu Haţieganu” University of Medicine and \\ Pharmacy, 12 Ion Creangă Street, 400010, Cluj-Napoca, Romania
}

*corresponding author: ofelia.crisan@umfcluj.ro

Manuscript received: March 2017

\begin{abstract}
The purpose of this paper is to research the standards for quality of pharmacy services included in national and international guidelines on good pharmacy practice. The documents were investigated using the comparative method and methods of legal interpretation. The Joint FIP/WHO Guidelines recommend national standards for procurement, storage, preparation, dispensing, medication therapy management and improving effectiveness of the health-care system and public health. The Romanian regulations establish standards for procurement, storage, preparation, dispensing, patient information and the rational use of medicines. However, they could be optimized by setting out standards for quality of the role of pharmacists in providing medication therapy management as well as their contribution to improving the effectiveness of the national health-care system.
\end{abstract}

\section{Rezumat}

Scopul lucrării este cercetarea standardelor de calitate pentru activitatea farmaciei, incluse în regulile de bună practică farmaceutică adoptate la nivel naţional şi internaţional. În acest scop s-au utilizat metoda comparativă şi metodele interpretării juridice. Ghidul FIP/OMS recomandă elaborarea de standarde naţionale pentru aprovizionarea, conservarea, prepararea şi eliberarea medicamentelor, furnizarea unui management eficient al terapiei medicamentoase, contribuţia la îmbunătăţirea sănătăţii publice şi a eficienţei sistemului sanitar. Reglementările româneşti stabilesc standarde de calitate pentru aprovizionarea, conservarea, prepararea şi eliberarea medicamentelor, informarea pacientului şi încurajarea utilizării raţionale a medicamentelor. Ele ar putea fi optimizate prin elaborarea de standarde de calitate pentru activităţile care definesc rolul farmacistului în managementul terapiei pacientului, respectiv contribuţia sa la creşterea eficienţei sistemului sanitar naţional.

Keywords: good pharmacy practice, standards for quality, procedures

\section{Introduction}

The quality of pharmacy services represents a major concern for the professional associations of pharmacists as well as for health authorities and patients. Although, in numerous countries pharmaceutical care has become an important component of professional practice in pharmacy, it could be improved, especially by providing education to pharmacists $[8-11,14,17]$. Some authors believe that the efficient functioning of a pharmacy greatly depends on the management of the available space, staff training and automatization [10, 17]. Appropriate policies and procedures that match the reality in different countries or regions are also required, especially as far as the supply of medicines, the resources required for quality services, patient satisfaction and adherence are concerned $[5,11,15,18]$. Important benefits could be gained by involving pharmacists in the political decision-making process in this field, since they generally have a good understanding of their community of patients $[16,18]$. The role of pharmacists in pharmacy is no longer confined to dispensing medicines but has developed towards patient treatment management $[6,11,15]$.
By including pharmacists, especially those with competencies in clinical pharmacy, in the medical team, the quality of health services increases not only in the case of patients with mild diseases treated with OTC products, but especially in complicated chronic cases $[6,11,14,15]$. In order to assure the quality of all these services, appropriate standards and operating procedures must be set out according to the principles of good pharmacy practice. Good pharmacy practice includes rules that govern pharmacy services in order to assure their quality and provide appropriate patient services. The International Pharmaceutical Federation (FIP) and World Health Organization (WHO) created the most important international documents regarding good pharmacy practice, the most recent being the Joint Guidelines adopted in 2011 [19-21]. In Romania, good pharmacy practice rules were first introduced by Order of the Minister of Health no. 1552/2004 [12], which failed to be implemented. This order was repealed by Order of the Minister of Health no. 75/2010, which adopted the good pharmacy practice rules currently in force [13]. In order to implement these rules, the College of Pharmacists of Romania organized training programs 
FARMACIA, 2019, Vol. 67, 3

for pharmacists and created procedure models for key pharmacy services, as well as procedures for the evaluation of compliance with good pharmacy practice rules [1-3].

The aim of this paper is to research the standards for quality of pharmacy services included in national and international guidelines on good pharmacy practice. The objectives are to analyse the standards for quality included in the Joint FIP/WHO Guidelines on good pharmacy practice and the Romanian regulations in force, to compare the two in order to identify any differences and to draw proposals for better national regulations in the field.

\section{Materials and Methods}

The following materials were used in this research: Joint FIP/WHO Guidelines on good pharmacy practice: standards for quality of pharmacy services, adopted in 2011 [21]; Order of the Minister of Health no. $75 / 2010$ for approving the regulations for good pharmacy practice [13]; procedure models for the application of regulations for good pharmacy practice in community and hospital pharmacies, created under the aegis of the College of Pharmacists of Romania $[1,2]$; Decision no. 1/2011 of the College of Pharmacists of Romania regarding the approval of procedures for the evaluation of compliance with the Regulations for good pharmacy practice [3].

These documents were studied using the comparative method and methods of legal interpretation [4, 7]. Comparison determined the structure of the paper, which comprises the analytical presentation of each compared element, including an individual analysis of both national regulations and international guidelines, together with a comparative synthesis focusing on similarities and differences between the compared terms [4]. The main criteria for analysis and comparison were the standards for quality of pharmacy premises and equipment, pharmacy staff and services.

\section{Results and Discussion}

\section{National regulations}

The Order of the Minister of Health no. 75/2010 includes rules of good practice applicable to some pharmacy services. Thus, this order establishes standards for quality of pharmacy premises, equipment and staff, as well as of the most important services offered by a pharmacy: preparation and dispensing of medicines, patient information and encouraging the rational use of medicines [13]. Standards for quality of other pharmacy services are either not mentioned, or they are included among those referring to other services. Thus, some standards for quality regarding the supply of medicines are included in the chapter on the dispensing of medicines and some standards for quality regarding the preservation and storage of medicines are included in the chapter on pharmacy premises and equipment. The standards regarding reception are included in the chapter on the preparation of medicines, although they only refer to pharmaceutical substances and not to all medicines and other health products, as they should in order to assure the quality of the products entered into the pharmacy stock and their traceability. There are no standards for quality of medicine storage according to traditional criteria (route of administration, pharmaceutical form, alphabetical order, validity date), the return of medicines, their recall from the market, the identification of falsified products, the storage and disposal of expired, degraded or returned medicines. There are no standards for quality regarding the provision of other services such as the assessment of biological parameters, the administration of medicines or other health products including vaccines, or the dispensing of medicines for veterinary use. There are no standards for quality of the relation between community pharmacies and hospitals or other inpatient healthcare facilities, in case these do not have their own pharmacy. Also, there are no standards for quality of specific services provided by hospital pharmacies such as the distribution of medicines and other health products to hospital departments or the activity of clinical pharmacists. Some of these shortcomings were remedied by the College of Pharmacists, which, in order to help pharmacists conform to the standards for quality established by good pharmacy practice rules, created models of standard operating procedures for the most important services offered by community and hospital pharmacies: the management of pharmacy premises and equipment, staff management, the procurement, reception, storage, return, recall, preparation and dispensing of medicines and other health products, the disposal of expired pharmaceutical products, the assurance of hygienic conditions, the provision of other pharmacy services, the solving of complaints and the assurance of traceability $[1,2]$.

As far as the standards for quality of pharmacy premises and equipment are concerned, we believe that the following contribute greatly to the creation of the health space that pharmacies should embody: creating the pharmacy must be the responsibility of the future chief pharmacist, who takes part in all stages of the authorization process, even if, according to the Romanian legislation, pharmacy owners need not necessarily to be pharmacists; the location of the pharmacy must be accessible to all potential patients, including elderly and/or disabled persons, and the pharmacy displays must promote health programs; a screened area is recommended in order to ensure patient confidentiality; besides specific equipment, the pharmacy must have the complete legal and professional documentation for proper functioning. As far as the standards for quality of pharmacy staff are concerned, we believe that the following can be regarded as the most significant for the lifelong 
professional development of pharmacists: the obligation of all staff members to know and respect the rights of the patients who seek pharmacy services, the obligation to plan and assess the continuing education of pharmacy staff according to specific needs, the analysis of the practical applicability of the knowledge and competences acquired through continuing education programs.

The standards for quality of pharmacy services were greatly developed by the College of Pharmacists, in comparison with those established by the Order no. $75 / 2010$. We believe that the most important standards for improving the quality of pharmacy services in Romania are as follows: procurement in order to provide patients with authorized, quality and accessible products that allow treatment continuation and encourage the rational use of resources; correct product reception as far as qualitative, quantitative and value standards are concerned, including rules for resolving nonconformities and for assuring the traceability of all the products and services offered by the pharmacy; checking the validity dates of products, temperature and humidity conditions, separate storage of expired or returned products and initiation of the procedure for disposal according to category of waste; the return and recall from the market of products, including interaction with the competent authorities in such situations; preparing medicines according to special rules and categories for magistral, officinal, traditional and homeopathic formulas, although preparation has become optional in Romanian pharmacies; respecting appropriate communication rules and the specific rules of pharmaceutical care when dispensing medicines, even in emergency situations; dispensing other health products according to specific rules for medical devices, hygiene and cosmetic products, food supplements, other herbal products and products for children; supplying other services and respecting specific rules for the measurement of arterial tension and blood sugar levels; resolving complaints regarding the products and services offered by the pharmacy; this falls under the responsibility of the chief pharmacist and must be carried out in accordance with patients' rights.

Although the procedure models established under the aegis of the College of Pharmacists were very useful for pharmacies at the beginning of the campaign for the implementation of good pharmacy practice rules, they only contain general specifications for every activity mentioned. This is why each pharmacy needs to create their own standard operating procedures for the services offered and to update these according to developments in the field, the current legislation and their own services.

The degree of implementation of good practice rules is assessed yearly by evaluators appointed by the College of Pharmacists. This evaluation is carried out according to an assessment grid approved by the Decision no. $1 / 2011$. The grid contains indicators referring to the pharmacy license, outdoor signs and opening hours, premises and equipment, staff, preparation and dispensing of medicines and other health products. It also includes potential measures to be taken in case minimum standards are not met and sets deadlines for solving these issues [3]. However, although the procedures established under the aegis of the College of Pharmacists contain standards for quality of the most important pharmacy services/ activities, not all these standards were included in the assessment grid. The following fall under this category: assuring pharmacy access for disabled persons; the cleanliness of the pharmacy at the time of evaluation; pharmacists initiating and/or participating in public health programs; pharmacists participating in continuing professional education; the evaluation and self-evaluation of professional development, including training in the field of good pharmacy practice; some pharmacy services: procurement, reception, assuring the traceability of medicines, preparation in pharmacy and other services, such as the assessment of biological parameters; knowing and respecting the patients' rights regarding pharmacy services.

Therefore, we believe that the assessment grid should contain indicators for all the aspects related to the quality of services offered by both community and hospital pharmacies.

Joint FIP/WHO Guidelines

The Joint FIP/WHO Guidelines set out the definition, requirements and need to create standards for good pharmacy practice. The guidelines also recommend that based on this document, national professional organizations establish minimum national standards for services promoting the role and functions of pharmacists according to local needs and the goals of the profession [21].

The guidelines do not refer to the standards for quality of pharmacy premises, except for stipulating the need for a suitable space that ensures patient confidentiality. The pharmacy equipment is also not covered by the guidelines, which only include some recommendations for appropriate standards for quality of preparation equipment, as well as of suitable storage conditions of all the products in the pharmacy or in the health establishment that the pharmacy belongs to. As far as the standards for quality of pharmacy staff are concerned, we regard the recommendations for the professional development of pharmacists in complementary and alternative therapies, as well as in the new technologies and automatization to be a very modern approach in line with the development pace of the present-day society. The Joint FIP/WHO Guidelines recommend standards for quality of traditional pharmacy services (procurement, storage, preservation, preparation, distribution, dispensing and disposal of medicinal products), plus standards 
FARMACIA, 2019, Vol. 67, 3

for quality of modern pharmacy services such as the administration of medicines, patient medication management and the pharmacist's contribution to the effectiveness of the health-care system and public health [21].

In the context of the international development of the legislation against the falsification of medicines, we believe that the most important standards for quality regarding the procurement and distribution of medicines are those that ensure the protection of patients: transparent, professional and ethical procurement of medicines; preventing the use of falsified medicines, including patient education regarding online sources of information; quick and effective recall of falsified products from the market under the responsibility of a specially designated person, such as one of the pharmacists in the pharmacy; involving pharmacists in public policies regarding the access of the population to quality essential medicines, including in case of disasters or pandemics.

The Joint FIP/WHO Guidelines suggest the creation of standards for quality of the administration of medicines in pharmacy, including results monitoring, as well as involvement in vaccination programs for better coverage of the population and safe vaccination [21]. The development of pharmacy services to include the administration of injectable medicines, especially vaccines, requires not only adequate staff training (vaccines, procedures), but also a redesign of the pharmacy premises in order to assure patient privacy. This development of pharmacy services also results in the production of more complex waste (medicines, medical devices, including devices contaminated with biological fluids, etc.). Therefore, special, updated rules are required in order to manage safe disposal. In this respect, we would like to commend the recommendation that patients and the general public return any unwanted or expired medical products to the pharmacy in order to be safely disposed of [21]. Environmental protection and patient information are thus becoming key objectives for pharmacists in pharmacies.

As far as the management of the medicinal treatment of patients is concerned, we believe that the creation and implementation of standards for quality for the following aspects may have an essential role in improving its effectiveness through the services offered by pharmacists in pharmacies: the training of pharmacists in order to be able to fully evaluate a patient's health condition and needs, by taking into consideration the patient's level of education, cultural beliefs, physical and psychological status; collaboration with the patient in order to establish a treatment plan, achieve adherence, encourage patient responsibility, monitor results and support the patient throughout the treatment; active collaboration with prescribing physicians and other healthcare professionals in the patient's best interest; sources of information and lifelong professional development.

Besides standards for quality of preventive actions (education, screening) and public health promotion (support, participation in various program), the Joint FIP/WHO Guidelines recommend the creation of standards for quality of activities through which pharmacists in pharmacies could contribute to the effectiveness of the health-care system [21]. Within the current context of commercial and information pressure, we believe that the most important activities in this respect refer to patient education for the correct evaluation of the available information, and compliance with the ethical standards for pharmacy services.

\section{Comparative synthesis}

As far as the pharmacy premises and equipment are concerned, the most important similarities between the Joint FIP/WHO Guidelines and the Romanian regulations refer to the need for a screened area that ensures patient confidentiality/privacy, as well as the existence of appropriate conditions and equipment for the correct preservation and preparation of quality products in pharmacy. As far as the continuing professional development of pharmacy staff is concerned, both documents set out the need to plan and implement appropriate strategies in order to improve knowledge, skills and professional performance. Most standards for quality of procurement, storage, preservation, preparation and dispensing of medicinal products as well as those regarding patient information and counselling can also be found in both documents. The most important differences between the Joint FIP/WHO Guidelines and the Romanian regulations refer to the standards for quality of administration of medicines in pharmacy, participation of pharmacists in vaccination programs, role of pharmacists within medication therapy management and their contribution to the effectiveness of the national health-care system. Neither the Order of the Minister of Health no. $75 / 2010$, nor the regulations of the College of Pharmacists included good practice rules or established standards for quality and operating procedures for these activities.

In our opinion, in order to improve good pharmacy practice rules in Romania, both categories of national regulations must be updated. Moreover, principles of good practice and standards for quality must be set out for the following: procurement and reception of medicines, especially for avoiding the selling of falsified medicines; administration of medicines in pharmacy and participation in vaccination programs; informing pharmacists, assuring the quality of the information sources, professional development in the field of alternative therapies and the use of new technologies in medicine; collaborating with prescribing physicians and other healthcare professionals based on protocols agreed on by professional associations; 
pharmacists carrying out services in hospitals, especially clinical pharmacy duties; provision of effective medication therapy management, especially through the professional development of pharmacists in order to be able to thoroughly examine the patient's condition, evaluate the response to therapy, support adherence to treatment and encourage patients to take responsibility for their own health; contributing to the improvement of public health and the effectiveness of the health-care system, especially by educating patients to evaluate and use the available information on medicines, especially online resources, respecting ethical standards of practice as well as initiating and participating in public health projects.

\section{Conclusions}

The Joint FIP/WHO Guidelines rely on the full involvement of the pharmacist in therapy management together with the patient, patient monitoring during and after treatment, as well as the contribution of the pharmacist to the effectiveness of the healthcare system. All these are based on quality continuing professional development and on the correct informing of all partners involved in the treatment process, including at the initiative of the pharmacist, as the main source of knowledge in the field of medicines. The Romanian regulations focus greatly on organizational rules concerning the size, purpose and functional connection between the pharmacy rooms, pharmacy paperwork and some general rules regarding the preparation and dispensing of medicines. The Romanian regulations in the field of good pharmacy practice must be evaluated and updated according to the recommendations of the Joint FIP/WHO Guidelines and the current level of knowledge in the field.

The improvement of national regulations, coupled with an implementation strategy made possible through the collaboration between the College of Pharmacists and the Ministry of Health would contribute to developing the role of the Romanian pharmacist in medication therapy management with the purpose of promoting community health and increasing the effectiveness of the health-care system.

\section{References}

1. College of Pharmacists of Romania, Iacob S, (coordinator), Legislation and procedure models for the application of regulations for good pharmacy practice in a community pharmacy, 02.2011, http:// colegfarmbv.ro/legislatie/, (available in Romanian).

2. College of Pharmacists of Romania, Iacob S, (coordinator), Legislation and procedure models for the application of regulations for good pharmacy practice in a hospital pharmacy, 05.2011, http:// colegfarmbv.ro/legislatie/, (available in Romanian).

3. College of Pharmacists of Romania, Decision no. $1 / 2011$ regarding the approval of procedures for the evaluation of compliance with the regulations for good pharmacy practice, Official Journal of Romania, Part I, no. 170/2011, amended, (available in Romanian).

4. Constantinesco LJ, Treaty of comparative law, tome 2: Comparative method, Ed. All Educational, Bucharest, 1998; 4-39, 52-109, (available in Romanian).

5. De Oliveira LTDDG, da Silva CP, Guedes MD, de Oliveira Sousa ACD, The good pharmacy practice on Einstein Program at Paraisopolis Community. Einstein-Sao Paolo, 2016; 14(3): 415-419.

6. Downing DF, Coming of age: pharmacy practice in the $21^{\text {st }}$ century. Israel J Health Policy Res., 2015; 4(62): 15-18

7. Eremia MC, Juridical interpretation, Ed. All, Bucharest, 1998; 1-29, (available in Romanian).

8. Gokcekus L, Toklu HZ, Demirdamar R, Gumusel B, Dispensing practice in the community pharmacies in the Turkish Republic of Northern Cyprus. Int $J$ Clin Pharm., 2012; 34(2): 312-324.

9. Iorga M, Sztankovszky LZ, Soponaru C, Gardikiotis I, Pharmacists' attitude and practices about drug dispensing in Romania. Farmacia, 2015; 63(4): 601-606.

10. Mark MP, The general pharmacy work explored in the Netherlands. Pharm World Sci., 2008; 30(4): 353-359.

11. Minarikova D, Malovecka I, Foltan V, Patient choice of pharmacy and satisfaction with pharmaceutical care Slovak regional comparison. Farmacia, 2016; 64(3): 473-480.

12. Ministry of Health, Order no. 1552/2004 for approving the Regulations for good pharmacy practice, Official Journal of Romania, Part I, no. 1166/2004, (repealed, available in Romanian).

13. Ministry of Health, Order no. 75/2010 for approving the Regulations for good pharmacy practice, Official Journal of Romania, Part I, no. 91/2010, (available in Romanian).

14. Morken T, Fossum S, Horn AM, Granas AG, Selfefficacy in counselling in Norwegian chain pharmacies: a cross-sectional study. Res Soc Administrative Pharm., 2008; 4(4): 375-383.

15. NICE Quality and Productivity Case Studies, Bushloe End Surgery, A pharmacist-led ulcerative colitis review service: Improving medicines adherence in general practice, 02.10.2014, www.evidence.nhs. uk/qualityandproductivity.

16. Romain S, Kohler J, Young K, Policy versus practice: a community-based qualitative study of the realities of pharmacy services in Nunavut, Canada. J Pharm Policy Pract., 2015; 8(1): 22:1-13.

17. Tăerel AE, Soroceanu V, Rais C, Stancu E, Study of quality standards application in Bucharest community pharmacies. Farmacia, 2014; 62(6): 1082-1088.

18. Winslade N, Taylor L, Shi S, Schuwirth L, Van der Vleuten C, Tamblyn R, Monitoring Community Pharmacist's Quality of Care: A feasibility study of using pharmacy claims data to assess performance. BMC Health Serv Res., 2011; 11(1): 12: 1-8.

19. World Health Organization, Good Pharmacy Practice (GPP) in Community and Hospital Pharmacy Settings, 1996; http://apps.who.int/medicinedocs/documents/ s21088en/s21088en.pdf.

20. World Health Organization, International Pharmaceutical Federation, Good pharmacy practice in community and 
FARMACIA, 2019, Vol. 67, 3

hospital pharmacy settings, WHO Tehnical Report Series, No. 885, 1999; Annex 7: 93-101, http:// infocollections.org/medregpack/documents/d0018/ d0018.pdf.

21. World Health Organization, International Pharmaceutical Federation, Joint FIP/WHO Guidelines on Good
Pharmacy Practice: Standards for Quality of Pharmacy Services, WHO Technical Report Series, No. 961, 2011; Annex 8: 310-323, www.who.int/medicines/ areas/quality_safety/quality_assurance/FIPWHOGu idelinesGoodPharmacyPracticeTRS961Annex8.pdf. 